\title{
Re-Inventing Infectious Disease: Antibiotic Resistance and Drug Development at the Bayer Company 1945-80
}

\author{
CHRISTOPH GRADMANN * \\ University of Oslo, Institute of Health and Society, Section for Medical Anthropology \\ and Medical History, P.O. Box 1130 Blindern, 0318 Oslo, Norway
}

\begin{abstract}
This paper analyses how research on antibiotic resistance has been a driving force in the development of new antibiotics. Drug resistance, while being a problem for physicians and patients, offers attractive perspectives for those who research and develop new medicines. It imposes limits on the usability of older medicines and simultaneously modifies pathologies in a way that opens markets for new treatments. Studying resistance can thus be an important part of developing and marketing antibiotics.
\end{abstract}

The chosen example is that of the German pharmaceutical company Bayer. Before World War Two, Bayer had pioneered the development of anti-infective chemotherapy, sulpha drugs in particular, but had missed the boat when it came to fungal antibiotics. Exacerbated by the effects of war, Bayer's world market presence, which had been considerable prior to the war, had plummeted. In this critical situation, the company opted for a development strategy that tried to capitalise on the problems created by the use of first-generation antibiotics. Part and parcel of this strategy was monitoring what can be called the structural change of infectious disease. In practice, this meant to focus on pathologies resulting from resistance and hospital infections. In addition, Bayer also focused on lifestyle pathologies such as athlete's foot. This paper will follow drug development and marketing at Bayer from 1945 to about 1980. In

\footnotetext{
* Email address for correspondence: Christoph.gradmann@medisin.uio.no

This article grew from a presentation on the conference 'Beyond the Magic Bullet: Reframing the History of Antibiotics', held in Oslo, March 2011, organised by Flurin Condrau (Zürich) and the author. The meeting was part of the European Science Foundation's Research Network Program 'Standard Drugs and Drug Standards' activities and the paper is deeply influenced by working on that network. Flurin Condrau, Class Kirchhelle (Oxford), Viviane Quirke (Oxford), María Jesús Santesmases (Madrid) and several anonymous reviewers delivered helpful comments to the manuscript. Working on the subject would have been impossible without the generous support that I received in the archive of the Bayer AG, Leverkusen, by Hans-Hermann Pogarell in particular. During revisions, Jean-Paul Gaudillière (Paris) and Ulrike Thoms (Berlin) graciously shared their unpublished work with the author. Viviane Quirke has also helped me to improve the usage of the manuscript.
} 
this period, Bayer managed to regain some of its previous standing in markets but could not escape from the overall crisis of anti-infective drug development from the 1970s on.

Keywords: Drug development, Bayer company, Infectious disease, Antibiotic resistance, Tuberculosis, Staphylococcal infections

\section{The End of Antibiotics}

In August 1992, Science, not usually a journal that specialises in historical research, had some sad news from recent history to deliver to its readers: the end of the antibiotic era had come. Fifty years after that class of medicines had been invented, a wave of drug resistant strains of microbes was about to frustrate decades of progress in infection medicine. Hospitals, where, if we follow the perspective of the paper in Science, patients suffering from infections had become a rare sight in preceding decades, had turned into places where the most dangerous microbes preyed on inmates. 'When these new drug-resistant strains become endemic in hospitals, you will be safer staying home than going to a hospital' ${ }^{1}$ an aghast doctor was quoted as saying. The editorial bore the title The Microbial Wars and left little room for doubt that, for the time being, it was the microbes who had won this war. As Mitchell Cohen wrote in another paper in the same Science issue, if there was one lesson that antimicrobial resistance taught it was the promise that a 'post-antimicrobial era' was about to unfold. ${ }^{2}$ Science was, of course, not the only purveyor of such news. During the late 1980s and early 1990s, we find the air humming with stories about the return of old and the arrival of new diseases - of superbugs that had outsmarted the former super drugs. ${ }^{3}$ The 1990s were, as the editor of the journal Infection, Genetics and Evolution put it, the 'golden age of genetics and the dark age of infectious diseases'. ${ }^{4}$

While authors of such gloomy prophecies could differ in their wording, they usually pointed to one and the same reason for why the antibiotic age had come to an end: the seemingly unstoppable rise of antibiotic resistance. ${ }^{5}$ The same class of medicines that for

\footnotetext{
${ }^{1}$ Daniel E. Koshland, 'The Microbial Wars', Science, 257, (1992), 1021. A scholarly monograph on the history of hospital infections Graham A.J. Ayliffe and Mary P. English, Hospital Infection From Miasmas to MRSA (Cambridge: Cambridge University Press, 2003), 134-70 seems to confirm the lines of development presented by Koshland: it describes a substantial improvement in relation to hospital infections occurring in the early twentieth century which was threatened by consequences of widespread antibiotic use after World War Two.

${ }^{2}$ Mitchell L. Cohen, 'Epidemiology of Drug Resistance: Implications for a Post-Antimicrobial Era', Science, 257 (1992), 1050-5.

${ }^{3}$ L.A. Reyolds and E.M. Tansey (eds), Superbugs and Superdrugs: A History of MRSA, (London: Wellcome Trust Centre for the History of Medicine at UCL 2008); Robert Bud, Penicillin: Triumph and Tragedy (Oxford: Oxford University Press, 2007); Nicholas B. King, 'The Scale Politics of Emerging Diseases', Osiris, 19, (2004), 62-76; David Satcher, 'Emerging Infections: Getting Ahead of the Curve', Emerging Infectious Diseases, 1, (1995), 6; Joshua Lederberg, Robert E. Shope and Stanley C. Oaks (eds), Emerging Infections. Microbial Threats to Health in the United States (Washington, DC: National Academic Press, 1992).

${ }^{4}$ Michel Tibayrenc, 'The Golden Age of Genetics and the Dark Age of Infectious Diseases', Infection, Genetics and Evolution, 1 (2001), 1-2.

${ }^{5}$ William C. Summers, 'Microbial drug resistance: a historical perspective', in R.G. Wax et al. (eds), Bacterial Resistance to Antimicrobials (Boca Raton, FL: CRC Press, 2008), 1-9; Frank Ryan, The Forgotten Plague: How the Battle Against Tuberculosis Was Won - and Lost (Boston: Little, Brown, 1993); Claudia Eberhardt-Metzger and Renate Ries, Verkannt und heimtükisch - Die ungebrochene Macht der Seuchen (Basel: Birkhäuser, 1996); H. Schadewaldt (ed.) Die Rückkehr der Seuchen (Köln: vgs, 1994).
} 
Frank M. Burnet in the 1950s had promised 'the virtual elimination of infectious diseases as a significant factor in social life ${ }^{6}$ had now been rendered useless by an increase in antibiotic resistance that went unchecked by pharmacological innovation. We might be tempted to discard such statements as yet another case of a typical 1980s doomsday prophecy, yet they seemed to correspond to reality: ${ }^{7}$ around 1990 , the pharmaceutical industry experienced an innovation crisis that included anti-infective medicines but was not limited to them. ${ }^{8}$ Awareness of what has become known as the empty pipeline syndrome seems to have originated in those days. ${ }^{9}$ Ever, the empty pipeline syndrome has proven to be a remarkably stable framing. When the director of the Centers for Disease Control and Prevention (CDC) presented a report on antimicrobial resistance to the public on 18 September 2013, he reiterated the warning that "we risk entering a post antibiotic era where even a simple infection can be deadly.' ${ }^{10}$ With 20 years of hindsight, it seems reasonable to say that the age of the therapeutic revolution that had characterised mid-twentieth-century medicine and pharmacology had come to an end by that time. ${ }^{11}$

At the same time, the notion of the end of antibiotics that became so popular around 1990 presupposes an explanation of how this situation had come about. Often invoked, this narrative ascribed the end of the therapeutic revolution to an arms race between biology and technology that industry had lost to more ingenious microbes. ${ }^{12}$ It is precisely this notion that the paper would like to question and it will do so along two lines: first, it will challenge the idea that the pharmaceutical industry reacted defensively to resistance. Instead, industry embraced the phenomenon, not least since resistance seemed to create exciting new markets for antibiotics. Secondly, the paper will challenge the notion that it was the rise of resistance alone that caused the 1980s innovation crisis. Instead, the paper claims that the situation resulted from consciously pursued strategies of research and marketing. In a wider sense, the innovation crisis will be discussed against the backdrop of the so-called eclipse of the therapeutic revolution, which was making itself felt towards the end of the twentieth century.

Focusing on the development of anti-infective medicines at the German pharmaceutical company Bayer, the paper is structured in four parts. Opening with a few general considerations on what developing and marketing anti-infective drugs in the twentieth century entailed, it explains why studying antibiotic resistance was part of Bayer's

\footnotetext{
${ }^{6}$ Frank Macfarlane Burnet, The Natural History of Infectious Disease (Cambridge: Cambridge University Press, 1953), 1940 ix.

${ }^{7}$ Kai F. Hünemörder, 'Kassandra im modernen Gewand. Die umweltapokalyptischen Mahnrufe der frühen 1970er Jahre', in F. Uekötter and J. Hohensee (eds), Wird Kassandra heiser? Die Geschichte falscher Ökoalarme (Stuttgart: Steiner, 2004), 78-97.

${ }^{8}$ David Greenwood, Antimicrobial Drugs. Chronicle of a Twentieth Century Triumph (Oxford: Oxford University Press, 2008) 262-3.

9 Ibid.: 262/3; Humphrey P. Rang, 'The development of the pharmaceutical industry', in H.P. Rang (ed.), Drug Discovery and Development: Technology in Transition (London: Churchill Livingstone, 2005), 3-18, here 16/7; Brad Spellberg et al., 'Trends in Antimicrobial Drug Development: Implications for the Future', Clinical Infectious Diseases, 38, (2004), 1279-86. Cf. Maryn McKenna's blog on the empty pipeline: http://www.super bugtheblog.com/2009/11/antibiotics-eu-pipeline-is-empty-too.html. See Maryn McKenna, Suberbug: The Fatal Menace of MRSA (New York: Free Press, 2010), ch. 12 on the end of antibiotics.

${ }^{10}$ Author's transcription from http://www.youtube.com/watch?v=uZt6q2uwM2g. Cf. Centers for Disease Control and Prevention (CDC) (ed.) Antibiotic Resistance Threats in the United States, 2013 (CDC, 2013).

${ }^{11}$ Christian Bonah et al., 'Standard drugs and drug standards. A comparative historical study of pharmaceuticals in the 20th-century', in C. Bonah et al. (ed.), Harmonizing Drugs. Standards in 20th-Century Pharmaceutical History (Paris: Editions Glyphe, 2009), 17-27.

12 Eberhardt-Metzger and Ries, op. cit. (note 5); Schadewaldt, op. cit. (note 5); Ryan, op. cit. (note 5).
} 
research from the very outset. In a second step, the paper analyses Bayer's work on antitubercular drugs around 1950, where monitoring resistance became a crucial part of drug development. The third part shows how the company's decision to specialise in antibiotics for the hospital market in the early 1960s resulted from its focus on bacterial resistance. In addition, the paper looks at Bayer's related investment into what can be called lifestyle infections. After analysing the state of antibiotics development around 1980, the paper finally returns to the initial hypothesis that the end of antibiotics, as was proclaimed around 1990, was not caused by a high tide of resistance alone, but also reflected a low tide of industrial investments that had begun a decade earlier.

\section{Understanding Drug Action and Studying Resistance}

When it comes to producing anti-infective medicines, Bayer had been one of the pioneers of that field around 1900. However, the approach was not based on searching for therapeutic molecules amongst microscopic fungi, which became the source of modern antibiotics. Instead, Bayer's research reflected the company's origins in producing synthetic dyestuffs. ${ }^{13}$ When developing medicines, researchers at Bayer usually relied on synthetic organic chemistry rather than microbiological screening. Such an approach was widespread in German pharmaceutical industry where important companies had a legacy of being producers of synthetic dyestuffs. ${ }^{14}$ In 1910, Hoechst, a company with a comparable profile and later Bayer's partner in IG Farben during the interwar years, pioneered modern anti-infective chemotherapy with the development of a treatment for syphilis, Salvarsan. ${ }^{15}$ This medicine had been developed in cooperation with the immunologist Paul Ehrlich and it was through Ehrlich's work on experimental chemotherapy that studying antibiotic resistance became part of drug development in the company's research department. As early as 1907, Ehrlich observed the occurrence of resistance while testing arsenicals in relation to parasitic infections and described it as a stable, inheritable and specific trait of certain microbes, which could, for instance, be bred into strains. The phenomenon seemed to be of little clinical relevance, since it was not observed when the drug in question, atoxyl, was applied on a large scale in Africa. ${ }^{16}$ Ehrlich assumed that resistance could be employed as a model of parasitedrug interaction. After all, it provided some - alas, negative - proof for the existence of pathways into parasite cells, so-called chemo receptors. ${ }^{17}$ When, in 1910, one of Ehrlich's

\footnotetext{
${ }^{13}$ Gottfried Plumpe, Die I.G. Farbenindustrie AG: Wirtschaft, Technik und Politik 1904-45 (Berlin: Dunker \& Humblodt, 1990).

14 Wolfgang Wimmer, 'Wir haben fast immer was Neues': Gesundheitswesen und Innovation der PharmaIndustrie in Deutschland 1880-935 (Berlin: Duncker \& Humblodt, 1994).

${ }^{15}$ Lutz Sauerteig, 'Ethische Richtlinien, Patientenrechte und ärztliches Verhalten bei der Arzneimittelerprobung 1892-31', Medizinhistorisches Journal, 35, (2000), 303-34; Axel Cäsar Hüntelmann, Paul Ehrlich: Leben, Forschung, Ökonomien, Netzwerke (Göttingen: Wallstein, 2011).

${ }^{16}$ Christoph Gradmann, Laboratory Disease: Robert Koch's Medical Bacteriology (Baltimore, MD: Johns Hopkins University Press, 2009), 213-25.

${ }^{17}$ Christoph Gradmann, 'Magic Bullets and Moving Targets: Antibiotic Resistance and Experimental Chemotherapy 1900-40’, Dynamis, 31, (2011), 305-21. Cf. Ehrlich's side chain theory: Cay-Rüdiger Prüll, Andreas-Holger Maehle and Robert Francis Halliwell, A Short History of the Drug Receptor Concept (Basingstoke: Palgrave, 2009); John Parascandola, 'The Theoretical Basis of Paul Ehrlich's Chemotherapy', Journal for the History of Medicine and Allied Sciences, 36, (1981), 19-43; Arthur Silverstein, Paul Ehrlich's Receptor Immunology: The Magnificent Obsession (San Diego, CA: Academic Press, 2003).
} 
pupils, Wilhelm Röhl, became head of Bayer's pathological laboratory, he would employ induced resistance as an ex-negativo model of drug action on the cellular level. ${ }^{18}$ Probably reflecting Bayer's strong commitment to antiparasitics, the drugs that came out of Röhl's laboratory in the following decades were effective against tropical parasitic infections such as sleeping sickness or malaria. ${ }^{19}$ The company's pre-World War Two career as a producer of anti-infectives peaked in the 1930s when, while technically being part of the conglomerate IG Farben, Bayer launched the first sulpha drug, Prontosil. ${ }^{20}$ This medicine was the hallmark of Bayer's inter-war strategy regarding anti-infective drug development that was based on the chemical synthesis of effective molecules. ${ }^{21}$ At the brink of the Second World War, Bayer was indeed a major pharmaceutical company, holding a seventeen per cent share of the world market in $1938 .^{22}$ Bayer was also a pioneer in socalled ethical drug marketing that was based on addressing physicians rather than their patients and providing information in the form of scientifically grounded claims rather than blunt advertisement. ${ }^{23}$ When it comes to anti-infectives, the company's portfolio boasted medicines addressing such conditions as malaria, sleeping sickness, pneumonia or sepsis. Taken in their entirety, such medicines also provide some insight into how the market for anti-infective medicines was framed in those days: commercial attention focused on infectious diseases with a high prevalence and high death rate; in other words on those conditions that had been defined as common infectious diseases by late nineteenth century medical bacteriology. ${ }^{24}$ Paul Ehrlich's grand design for anti-infective chemotherapy had aimed to target such conditions ${ }^{25}$ and Bayer's targeting of the anti-infectives market was similar. ${ }^{26}$ Tackling infectious disease was essentially framed as a conquest of common infectious disease - of nature itself, in fact. In the 1930s, this conquest seemed well under way. $^{27}$

18 Gradmann 2011, op. cit. (note 17).

${ }^{19}$ Horst Bernd Dünschede, Tropenmedizinische Forschung bei Bayer (Düsseldorf: Trilsch, 1971). Bayer Leverkusen Tropenabteilung, Die Chemotherapie der Schlafkrankheit (Leverkusen: Bayer, 1938).

${ }^{20}$ John E. Lesch, The First Miracle Drugs: How the Sulfa Drugs Transformed Medicine (Oxford: Oxford University Press, 2007); Cf. Axel A.H. Dalhoff, 'Discovery and Development of Anti-infectives at Bayer: A Personal View. Part I: Antiparasitics, Sulfonamides, and Antitubercular drugs', Sim News, 57, (2007), 135-50, here $135-42$.

${ }^{21}$ Wilhelm Bartmann, Zwischen Tradition und Fortschritt. Aus der Geschichte der Pharmabereiche von Bayer, Hoechst und Schering von 1935-75 (Stuttgart: Steiner, 2003), 106-12. Cf. John E. Lesch, 'Chemistry and biomedicine in an industrial setting: the invention of the sulfa drugs', in S.H. Mauskopf (ed.), Chemical Sciences in the Modern World (Philadelphia, PA, University of Pennsylvania Press, 1993), 158-215.

22 Hermann A. Baum, Geschichte der Pharma nach dem Zweiten Weltkrieg (Leverkusen: Bayer AG Leverkusen, 1983).

23 Jean-Paul Gaudillière and Ulrike Thoms, 'Pharmaceutical Firms and the Construction of Drug Markets: from Branding to Scientific Marketing', History and Technology, 29, (2013), 105-15; Ulrike Thoms, 'Standardizing Selling. Pharmaceutical marketing, the Pharmaceutical Company and the Marketing Expert (1900-80)', History and Technology, 29, (2013), 169-87.

${ }^{24}$ Silvia Berger, Bakterien in Krieg und Frieden: eine Geschichte der medizinischen Bakteriologie in Deutschland 1890-933 (Göttingen: Wallstein, 2009), 27-90.

25 Parascandola, op. cit. (note 17); Prüll, Maehle and Halliwell, op. cit. (note 17).

26 Dalhoff 2007, op. cit. (note 20); Axel A.H. Dalhoff, 'Discovery and Development of Anti-infectives at Bayer: A Personal View. Part II: B-lactam antibiotics', Sim News, 58, (2008), 6-18; Cf. Heiko Braun, 'Von der Vertriebsund "Propagandapolitik" zum Pharmamarketing? Eine Marketinggeschichte des deutschen Pharmabereichs der Farbenfrabriken Bayer AG 1957-71' (Unpublished M.A. thesis: University of Bonn, 2009).

${ }^{27}$ Charles-Edward Emory Winslow, The Conquest of Epidemic Disease: A Chapter in the History of Ideas (Princeton, NJ: Princeton University Press, 1987 (1967)). 


\section{In the Shadow of Streptomycin}

Now part of the conglomerate IG Farben, the Second World War created a host of challenges for Bayer and diminished the company's standing as a major producer of anti-infective medicines. As we all know, the Second World War saw the arrival of mass antibiotic therapy with sulphas and fungal antibiotics and the resulting arrival of resistant pathogens as a clinical phenomenon. ${ }^{28}$ The war also brought about changes to the German pharmaceutical industry that are of specific relevance to our story: most importantly, when it came to new developments, the boat of fungal antibiotics had been missed. ${ }^{29}$ The German pharmaceutical industry was practically not involved in the development of firstgeneration antibiotics such as penicillin or streptomycin. At the same time, American and British antibiotic producers now entered a greatly expanded a market that had previously been dominated by German companies. ${ }^{30}$ The challenges were substantial. In Bayer's case, this meant that a formerly innovative, major producer of medicines now had to rebuild a portfolio that, for the time being, was heavily reliant on licensed molecules. By the mid-1950s, Bayer's world market share had dropped like a stone. Interestingly, Bayer's production itself had not collapsed; by 1951, the company's pharmaceutical turnover had already regained the level it had had before the war. Yet, the world market had grown eightfold in that same period and Bayer had not participated in that growth. In 1938, turnover on the international market had been three times higher than that on the domestic market. In 1955, this proportion was reversed. The company was now a regional producer. $^{31}$

How Bayer tried to tackle such a situation can be shown by the example of antitubercular drugs. Prior to the war, the head of development, inventor of sulphas and Nobel Prize laureate Gerhard Domagk, ${ }^{32}$ had even advised to stay out of this field. Domagk's argument had been that tuberculosis represented a diminishing market because of its declining prevalence. What historians and epidemiologists have came to call the epidemiologic transition later on was beginning to make itself felt. ${ }^{33}$ After decades of more or less steady decline of tuberculosis' prevalence, Domagk noted that there was 'no vital necessity' for a medicine on the eve of the Second World War. ${ }^{34}$ During the war, however, that decision seems to have been reconsidered and Bayer's research on potential tuberculosis medications in preparation for the post-war economy actually started before the war

\footnotetext{
${ }^{28}$ Bud, op. cit. (note 3): 116-8; Lesch, op. cit. (note 20); For a contemporary account see John A. Kolmer, Penicillin Therapy. Including Streptomycin, Tyrothricin And Other Antibiotic Therapy 2nd ed. (New York; London: Appleton-Century, 1947 (1945)): 54-56.

${ }^{29}$ Jean-Paul Gaudillière and Bernd Gausemeier, 'Molding National Research Systems: the Introduction of Penicillin to Germany and France', Osiris, 20 (2005), 180-202.

${ }^{30}$ Bud, op. cit. (note 3): 23-53.

${ }^{31}$ Bartmann, op. cit. (note 21), 301-3. Cf. Patrick Kleedehn, Die Rückkehr auf den Weltmarkt. Die Internationalisierung der Bayer AG Leverkusen nach dem Zweiten Weltkrieg bis zum Jahre 1961 (Stuttgart: Franz Steiner Verlag, 2007), 151-63.

32 Ekkehard Grundmann, Gerhard Domagk - der erste Sieger über die Infektionskrankheiten (Münster: Lit, 2001).

${ }^{33}$ Francis Barrymore Smith, The Retreat of Tuberculosis 1850-950 (London: Croom Helm, 1987). For a contemporary account see V.C. Barry, The Chemotherapy of Tuberculosis (London: Butterworth, 1964). Cf. George Weisz and Jesse Olszynko-Gryn, 'The Theory of Epidemiologic Transition: The Origin of a Citation Classic', Journal for the History of Medicine and Allied Sciences, 65, (2009), 287-326.

${ }^{34}$ Domagk, unpublished memories, quoted in Dietrich Redeker, Zur Entwicklungsgeschichte der Tuberkulostatika und Antituberkulotika (Stuttgart: Deutscher Apotheker Verlag, 1990), 100.
} 
ended. ${ }^{35}$ In 1943, when a molecule with good antitubercular properties was under investigation, work was suspended and a patent was registered, but knowledge was shelved before it had reached the stage of clinical development. This decision presumably reflected experiences from the aftermath of the First World War, when patents for marketed drugs had been violated but allied control had not penetrated the company's developmental pipeline any deeper. ${ }^{36}$ When the war ended in 1945, Bayer's tentative wartime tuberculosis research suddenly seemed justified, when tuberculosis dramatically returned to the country: 'Suddenly, the creation of an effective therapy of tuberculosis for an impoverished and starving population became a pressing problem. ${ }^{37}$

However, the post-war world market was no longer a market in which Bayer held a dominant position. In part, this was due to political reasons, since, under occupying rule, access to foreign markets remained limited for decades to come. ${ }^{38}$ What was decisive, however, was that Bayer lacked innovative products and thus became a producer reliant on in-licensed medicines. As already mentioned, the success of fungal antibiotics had shifted power relations and previously smaller Anglo-American companies now outranked their German counterparts on the worldwide drug market. One consequence of this development was that German companies found themselves excluded from lucrative markets. When Bayer purchased a licence for the production of first-generation antibiotics from an American company, it was forced to restrain from selling these antibiotics on the large American market. ${ }^{39}$ While abstaining from cooperation in research and development in which it would have been a junior partner, like Spanish or Italian producers did, ${ }^{40}$ the international profile that the company had had before the war was beginning to feel like a dim memory. In terms of anti-tubercular medicines, the arrival of the potent antituberculosis antibiotic, streptomycin, in 1947 initially meant that Bayer's 1943 substance could have been shelved for good.

The company, however, refused to be relegated to the status of a regional producer and its first attempt to re-enter the market of antitubercular medicines was an attempt to challenge streptomycin head on. Development of the 1943 molecule, a thiosemicarbazone, was reinstated in 1946 and the medicine was marketed under the brand name Conteben from 1949. ${ }^{41}$ However, Conteben did not fare well in direct comparison with streptomycin: it was less effective, more toxic and could thus not be applied in high doses. ${ }^{42}$ Being classified as a third class drug by the American Veterans Organization did not help either, and Bayer seems to have silently withdrawn it from the market in the $1950 \mathrm{~s}^{43}$

\footnotetext{
35 Background: Dalhoff, op. cit. (note 20), 143-4; Redeker, op. cit. (note 34), 84-104.

36 Wimmer, op. cit. (note 14). According to Redeker, op. cit. (note 34), 90, a patent was registered in 1943.

37 Domagk, quoted in Redeker, op. cit. (note 34), 100.

38 Bartmann, op. cit. (note 21), 301-29.

39 That company was Schenley. It took Bayer almost 30 years before substantial turnover could be achieved in the US market. Ibid., 318-19. Cf. Kleedehn, op. cit. (note 31), 152-3.

${ }^{40}$ Mauro Capocci, " "A Chain is Gonna Come”. Building a Penicillin Production Plant in Post-war Italy', Dynamis, 31, (2011), 343-62; Maria Jesús Santemases, 'Screening Antibiotics: Industrial Research by CEPA and Merck in the 1950s', Dynamis, 31, (2011), 407-27.

${ }^{41}$ Redeker, op. cit. (note 34), 91, Dalhoff, op. cit. (note 20), 144, 146.

42 Redeker, op. cit. (note 34), 93.

${ }^{43}$ Ibid., 98, 104, Barry, op. cit. (note 33), 49.
} 
Despite streptomycin's therapeutic efficacy, a chink in its armour seemed to open a path for marketing other medicines: when applied alone, streptomycin produced resistant bacteria at a high rate. ${ }^{44}$ This unwelcome development could, however, be checked by combining it with another drug. The possibility of this approach was shown in 1948 when streptomycin and para aminosalicylic acid, known as PAS, were combined. The contemporary scientific explanation for the phenomenon was that the different drugs were effective against each other's resistant strains and thus checked the process of selection of resistant strains that mono-therapy brought about in a patient. ${ }^{45}$ Research on drug combination therapy was occurring in a situation where antimicrobial resistance was about to become a more widespread phenomenon. What had started with resistant gonococci during the war was, as a review paper noted, now also the case for tuberculosis:

As a result of too much dissemination bacteria are bred that are resistant to individual medicines. We have experienced this in gonococci: 10 to 15 years ago gonococci were much more sensitive to sulphonamides than today, where resistant strains have been bred. [...] It is a generally known that under the application of streptomycin over 2-6 month some bacteria will remain, which are no longer susceptible to streptomycin. ${ }^{46}$

Conteben, however, due to its relative toxicity, could not be administered in higher doses and over prolonged periods. Thus a combination therapy with streptomycin, modelled on the example of the latter's combination with PAS, was not an option for Bayer for the time being. ${ }^{47}$ Still, with streptomycin resistance on the increase, combination therapy appeared to open the door for other medicines. In order to market another one of its molecules, isonicotinylhydrazine, better known as isoniazid, Bayer decided that they should first learn more about resistance produced by streptomycin. Developing Bayer's brand of isoniazid, Neoteben, thus involved a large clinical development programme, which focused on the diagnosis and control of antibacterial resistance. ${ }^{48}$

A look at the actual process of Bayer's work on drug development is illuminating. Diagnosing resistance as a cause of failing therapies was not a simple undertaking in those days. Instead of simply identifying a species by cultivation, one had to determine specific strains of resistant microbes. It required the application of serological or phage testing that few hospitals, let alone practitioners, were able to do. ${ }^{49}$ Exploiting this situation, Bayer spread the word that they would do such testing in their laboratories. From the files in Bayer's archives, it becomes clear that within a short time this strategy resulted in a rather impressive library of resistant tuberculosis. That library was then used to design a therapeutic protocol on the combined application of streptomycin, isoniazid and PAS.

\footnotetext{
${ }^{44}$ Kolmer, op. cit. (note 28): 54-6, H.W. Florey et al. Antibiotics: A Survey of Penicillin, Streptomycin, and other Antimicrobial Substances from Fungi, Actinomycetes, Bacteria, and Plants (Oxford: Oxford University Press, 1949), 1365-400.

45 On this and the following, see Barry, op. cit. (note 33): 192-202. Cf. Redeker, op. cit. (note 34), 123.

${ }^{46}$ H. Dennig and H. Hangleiter, 'Der heutige Stand der Chemotherapie bakterieller Erkrankungen und der Infektionskrankheiten', Deutsche medizinische Wochenschrift, 76, (1951), 647-9; 680-2: here 647.

${ }^{47}$ Redeker, op. cit. (note 34), 104.

48 Archive of the Bayer AG, Leverkusen (BAL), 316/3.

49 Christoph Gradmann, 'Sensitive Matters. The World Health Organisation and Antibiotics Resistance Testing, 1945-75', Social History of Medicine, 26, (2013), 555-74. Cf. Kathryn Hillier, 'Babies and Bacteria: Phage Typing, Bacteriologists, and the Birth of Infection Control', Bulletin of the History of Medicine, 80, (2006), 733-61.
} 
Translation in excerpt

$[\cdots]$

Preparation to be inspected: $\quad$ Sputum of 17.9.53

Findings. $\quad$ Tb. Resistance determination started 2.10.53

Read 2.11.53

Result:

\begin{tabular}{|c|c|c|}
\hline Control: & \multicolumn{2}{|c|}{+++ dispersed cover } \\
\hline \multirow[t]{2}{*}{ Neoteben } & 1: $100000++$ & isolated colonies \\
\hline & $1: 10.000+$ & isolated colonies, countable \\
\hline \multirow[t]{2}{*}{ Pas } & $1: 10000+/-$ & less than 10 colonies \\
\hline & $1: 10000(+/-)$ & growth is only discernible under the microscope \\
\hline \multirow[t]{2}{*}{ Conteben: } & $1: 00000(+/-)$ & “، ، ، ، \\
\hline & 1:10000 & no growth \\
\hline \multirow[t]{2}{*}{ Streptomycin } & $1: 100000$ & less than 10 colonies \\
\hline & $1: 10000$ & “، « \\
\hline
\end{tabular}

The illustration (figure 1) shows a patient file from the clinical development programme of what became known as combination therapy. From the date, it is obvious that the programme was continued well beyond the marketing of Neoteben and Pasalon, Bayer's own brand of PAS, in 1951 and 1953 respectively. It was indeed difficult to say where research ended and marketing began. Resistance assays had been crucial in the entire process since they simultaneously served to establish and advertise the proposed effect. Resistance to streptomycin had created an opening for the marketing of a medicine for which there would have been no need otherwise. As mentioned, Bayer had, before the war, been a pioneer in ethical drug marketing. Basing advertisements on the statements of a trustworthy professional remained a common approach in post-war Germany. ${ }^{51}$ Consistently, Bayer's clinical development programme was accompanied by affirmative publications. As Ludwig Heilmeyer, Bayer's most important collaborator in clinical development, noted, 'Experiments undertaken with the aim of producing resistance, have shown that INH produces resistance at much slower rates. ${ }^{52}$ While isoniazid indeed proved to be a medicine of high efficacy and could be combined with streptomycin, Ludwig Heilmeyer's statement was still affirmative in character. In fact, that medicine became notorious for the high rate of resistance it produced and was thus best used in combination therapy. ${ }^{53}$

\footnotetext{
${ }^{50}$ BAL, 316/3.82.

51 Arthur Daemmrich, Pharmacopolitics: Drug Regulation in the United States and Germany (Chapel Hill, NC: University of North Carolina Press, 2004), 77-8.

52 Ludwig Heilmeyer, 'Vorläufiger Bericht über Isonikotinsäurehydrazid (Rimifon, Neoteben) auf Grund experimenteller und klinischer Untersuchungen', Deutsche medizinische Wochenschrift, 94, (1952), 1303-8.

53 Barry, op. cit. (note 33), 194-8. Redeker, op. cit. (note 34), 180-97 points to the affirmative character of Domagk's and his collaborators' statements.
} 


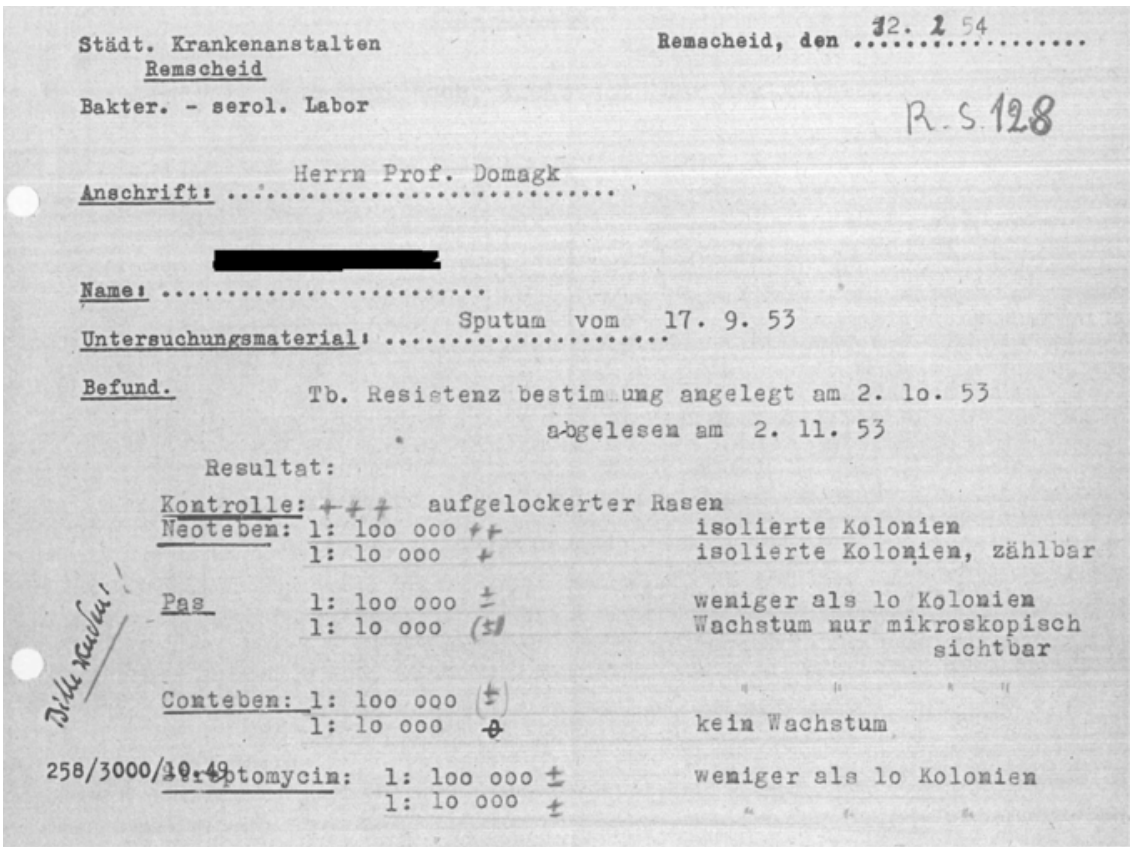

Figure 1: A tuberculosis culture sent from a hospital in February 1954 is checked for susceptibility against available medicines.

Gerhard Domagk was enthusiastic about the potential that resistance research and the marketing of combination therapies harboured. In 1958, he envisioned a bright future in which resistant tuberculosis was controlled for good - thanks to Bayer: 'Preparations, which will render the issue of resistance, which is so overrated today, irrelevant, could help to secure a unique position of pre-eminence in the field of antitubercular drugs to Bayer.' ${ }^{54}$ In his annual report for 1958 , Domagk also insisted that tuberculosis was an important market segment - with 260000 cases of pulmonary tuberculosis in West Germany alone, it must not be ignored. ${ }^{55}$ Managing tuberculosis in patients was all about preventing resistance from arising and in the 1950s, Domagk clearly aimed to command a portfolio of medicines that addressed this task. By combining their own developments like Neoteben with other drugs, Bayer launched several preparations that essentially packaged combination therapy in one pill. Significantly, one of these, Orthomycin, a combination of isoniazid and a streptomycin derivative, launched in 1953, was advertised (see figure 2) as ' $[\cdots]$ delaying the onset of chemo-resistance to single components and also [exerting] effects on germs resistant to Streptomycin and Neoteben' ${ }^{56}$

Combining two of Bayer's own molecules, Nicoteben, a combination of Neoteben and the revitalised Conteben, was launched in 1956 and followed the same rationale. In 1962, Domagk's successor as head of the pathological laboratory, Albert Michael Walter, maintained that Nicoteben had a better capability of controlling resistance than the

\footnotetext{
54 BAL 103/11.2. Annual report [Jahresbericht] for 1958.

55 Ibid., 1957.

${ }^{56}$ From Orthomycin advert of 1955, BAL 166/8.
} 


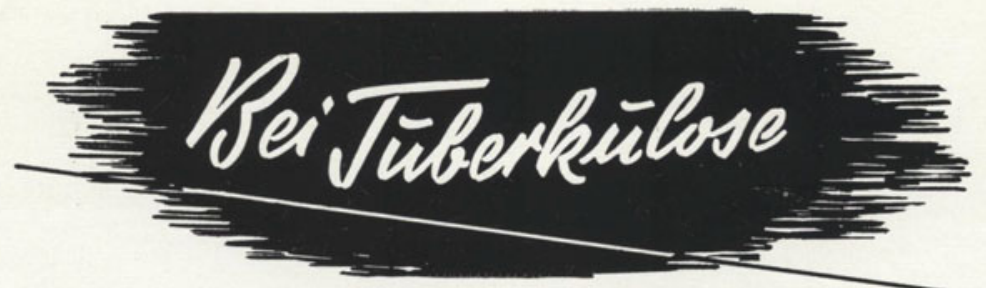

Zur kombinierten Therapie mit Neoteben + Streptomycin ORTHOMYCIN

„Neoteben" $0,3 \mathrm{~g}+$ krist. Dihydrostreptomycin-Sulfat, entsprechend $0,5 \mathrm{~g}$ Base

\section{ORTHOMYCIN,forte،}

„Neoteben" 0,3 g + krist. Dihydrostreptomycin-Sulfat, entsprechend 1,0 g Base

Sie vermögen die Entwicklung einer Chemoresistenz gegenüber den Einzelkomponenten hinauszuzögern und auch Streptomycin-bzw. Neoteben-resistente Keime zu beeinflussen.

Packungen: Je 1 Flasche + Lösungsmittelampulle

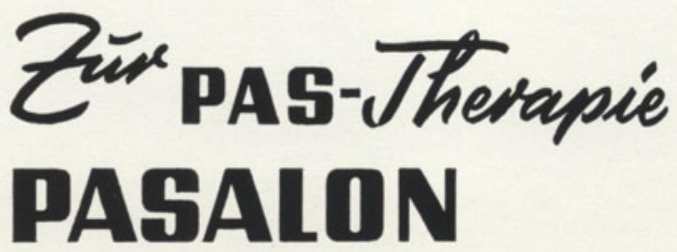

Als Trockensubstanz, Trockensubstanz steril,

Granulat, Dragees und als Pasalon-Calcium Dragees.
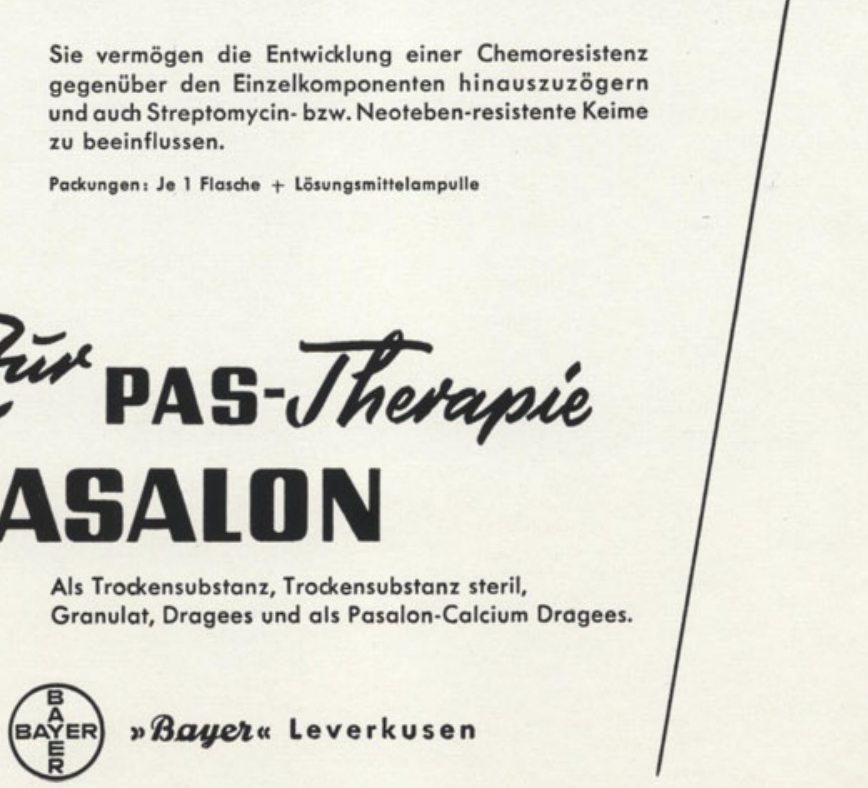

Figure 2: Advertisement for Orthomycin, mid-1950s, BAL, 166/8. 
common combination of streptomycin and PAS (for none of which Bayer held patents). ${ }^{57}$ While working on developing yet another antitubercular medicine in 1960, the strategy to be followed at Bayer's R\&D laboratories in Elberfeld was almost the same as in the early 1950s. Only this time, isoniazid, which Bayer had marketed as the answer to streptomycin resistance earlier on, became the target of that strategy: 'All the efforts at our laboratories in Elberfeld in creating a new tuberculostatic are focused on substances with efficacy against INH-resistant strains. ${ }^{58}$

\section{Reinventing Infectious Disease}

Rather than illustrating Bayer's comeback as a producer of anti-infectives, Domagk's statements, however, indicate the problems that the company was facing. To start with, earnings from tuberculosis combination therapy were not impressive. ${ }^{59}$ The reasons for this lay less in the protocol itself than in the chosen target for drug development. Following a short spike of new infections in the immediate post-war years, tuberculosis quickly returned to the path of decline that had characterised its pre-war history. To give an example, new infections for the large German state of North-Rhine Westphalia rose from 14.5 per 10000 inhabitants in 1938 to 41.7 in 1945, sliding to 32.9 in 1949 and dropping to 9.3 per 10000 in $1965 .^{60}$

Furthermore, the style of development practised under Domagk seemed outdated in two respects: firstly, it focused on major common infectious diseases, whose impact was diminishing. Secondly, it consciously avoided microbiological approaches and held on to synthetic chemistry that had paved the way to the sulpha drugs. Something that could not be expressed in a structural chemical formula had little chance of getting past the socalled department for chemical analysis that had a gatekeeper function in Bayer's research pipeline. In a consistent manner, Domagk's institute for pathology - in effect, Bayer's drug development department - did not employ a single microbiologist in the 1950s. Even in relation to the sulphas, Domagk's approach of prioritising potent medicines in favour of those which offered ease of use was out of date. While proposing the use of sulphas in many fields, Domagk failed to realise the attractions that so-called long-lasting preparations offered.

Curiously, Domagk seemed to be aware of the market opportunities created by resistant microbes. In his correspondence with a lung specialist in 1951, he stressed that resistant tuberculosis could become as prevalent as resistant gonococcus during the war (when sulphas had been mass-applied against them). Domagk's views also echoed calls for socalled rational application of antibiotics, which were becoming prevalent in those years: ${ }^{61}$

\footnotetext{
Regarding the application of sulphonamides, of penicillin and other antibiotics, a frequent misuse has crept in to apply these medicines quite indiscriminately and in high doses even in the case of light infections. This has to be avoided regarding tuberculosis at all costs. [...] If we let it happen, like with gonorrhoea, these resistant strains are propagated in the future, the result will be an endless race between chemotherapy and new infections. Nobody knows what the outcome will be. ${ }^{62}$

${ }^{57}$ BAL, 363/101, of 5.11.62.

${ }^{58}$ Bunge to Hansen, 2.11.1960, BAL, 367/626.

${ }^{59}$ Bartmann, op. cit. (note 21), 320.

${ }^{60}$ Ulrike Lindner, Gesundheitspolitik in der Nachkriegszeit: Grossbritannien und die Bundesrepublik Deutschland im Vergleich (München R. Oldenbourg 2004), 127-59. Cf. Smith, op. cit. (note 33).

${ }^{61}$ Scott H. Podolsky, 'Antibiotics and the Social History of the Controlled Clinical Trial', Journal for the History of Medicine and Allied Sciences, 65 (2010), 327-67.

62 Domagk to Kreutzer, 10.3.1951, BAL, 372/016.
} 
As early as 1953, he even identified resistant bacteria as a possible future market. Commenting on the increasing presence of resistant Staphylococcus in hospitals, he saw a bright future for Bayer's chemicals: 'Until now, the medicine of choice in staphylococcal infections was penicillin. The increasing presence of resistant strains of Staphylococcus (in some hospitals up to 50 and $60 \%$ ) creates yet another opening for chemotherapy. ${ }^{\text {,63 }}$ Yet, Domagk, it seems, also stubbornly clung to his greatest lifetime achievement, the sulphas, thereby perpetuating Bayer's isolation in terms of its chemical research focus. When approached repeatedly by the company's director of pharmaceutical development, Bunge, to come up with some new medicine that could tackle resistant Staphylococcus, Domagk insisted that this medicine had been invented long ago - and referred Bunge to one of Domagk's sulphonamides, Debenal. ${ }^{64}$ However, while future sales of sulphonamides such as Durenat (launched in 1960), did indeed profit from the declining applicability of first-generation antibiotics, ${ }^{65}$ there was little hope for the long-term success of a purely chemical-focused development strategy in the late 1950s. Even in this field, where Bayer was still strong, sales were sliding. This was, in part, due to a steadily declining popularity of sulphas as such. However, as the sales department dryly summarised in 1958, Bayer had done little to amend the situation: 'The group of sulphonamides is in a continuous decline; it fell by $15 \%$ in relation to the previous years. We have not participated in the modern development of sulphonamides. ${ }^{66}$

It was only in 1960 that a sweeping rearrangement of research and development came under way and it was bound up with some important changes in the history of antibiotic resistance that we briefly need to consider. Previously having being considered rare phenomena, antibiotic resistance gained increasing recognition from 1953 onwards, when an epidemic of penicillin resistant Staphylococcus literally swept around the planet. The spread of so-called Staph 80/81, named after the phages employed for its identification, brought the epidemic character of antibiotic resistance to researchers' attention and greatly boosted the field of clinical microbiology. ${ }^{67}$ At the same time, the obviously widespread presence of microbes no longer responding to penicillin initiated the development of penicillinase-resistant, semi-synthetic antibiotics that would live up to the challenge. ${ }^{68}$ Simultaneously, and to the dismay of therapeutic rationalists in internal medicine, combination antibiotics and so-called broad-spectrum antibiotics were becoming highly popular. $^{69}$

Shortly after Domagk's mildly enforced retirement in 1960, Bayer seized the occasion to redefine its antibiotic development strategy in relation to such challenges. Domagk had been firmly rooted in a non-clinical research tradition - he held a chair in pathology. By contrast, Albert Michael Walter, Domagk's successor, had a background in internal medicine. He had been trained at one of Bayer's most important collaborating hospitals,

63 Domagk, Annual report [Jahresbericht] 1953, BAL, 103/11.2, p. 23.

64 Domagk to Bunge, 10.11.1958, BAL, 372/24.

${ }^{65}$ Memorandum on the meeting of the "working group [Arbeitsgruppe] chemotherapeutics: antibiotics, sulphonamides, tubculostatics", 5.11.1962, BAL, 363/101.

66 Annual Report 1958 of pharmaceutical sales department [Jahresbericht für 1958 der Pharmazeutischen Verkaufsabteilung], BAL, 103/11.2. Cf. Bartmann, op. cit. (note 21), 321.

${ }^{67}$ Hillier, op. cit. (note 49).

${ }^{68}$ Bud, op. cit. (note 3), 116-39; Greenwood, op. cit. (note 8); E.M. Tansey (ed.) Post Penicillin Antibiotics: from Acceptance to Resistance. A Witness Seminar, held at the Wellcome Institute for the History of Medicine, London, 12 May 1998 (London: Wellcome Trust, 2000).

${ }^{69}$ Podolsky, op. cit. (note 61). 
the university clinic in Freiburg, where he had headed the clinical microbiology laboratory. Walter's thesis, written for his Habilitation - the German post-PhD exam that qualifies for a university chair - had dealt with the question of how to delay the onset of antimicrobial resistance by applying combination therapy. Being a pupil of Domagk's most important clinical collaborator in tuberculosis, Ludwig Heilmeyer, who was director of Freiburg University clinic of internal medicine, Walter had been investigating how to transpose what had become established for tuberculosis to other infections, notably, those caused by Staphylococcus aureus. ${ }^{70}$ With his former superior Heilmeyer, Walter had co-authored a popular textbook on antibiotic therapy. ${ }^{71}$ Before starting in his new position, Walter was sent on a training tour of US laboratories. According to Domagk, Walter was being hired to ride his hobby horse tuberculosis - that is to 'familiarize himself with experimental work on tuberculosis with the aim of taking over this field one day', ${ }^{72}$ and to take over Bayer's work on sulphonamides. However, once in office, Walter showed little interest in tuberculosis and instead expanded Bayer's portfolio in the direction of semi-synthetic antibiotics effective for a multiplicity of conditions.

There is evidence that the style of research in what used to be Domagk's laboratory changed substantially around his retirement. Focusing foremost on what can be called the structural change of infections, Walter directed drug development to where new and transformed pathologies were to be found: ie. to hospital medicine. This resulted in an intensification of the style of clinical development that Domagk had practised when isoniazid was developed. Probably also reflecting the now widespread laboratory capacities in many hospitals, Bayer's approach came to rely less on broadcasting their laboratory services in a rather random fashion, as had been the case in the early 1950s, but on collaborating closely with a limited number of hospitals. ${ }^{73}$ These hospitals turned into more than just providers of probes but functioned as collaborators. As Walter insisted, what mattered was to involve clinical expertise in pre- and post-marketing development of medicines. Competent collaborators would help with the development of those medicines and in turn their standing in the field would help to market those drugs. ${ }^{74}$ During the early 1960s, Bayer also tried to modify its purely chemical research approach. From 1961, the idea was formed to employ a microbiologist in drug development rather than relying exclusively on chemists, as the company had done so far. As a result, Karl Metzger, a specialist in microbiology, was hired in 1963. Bayer's turn to microbiology would later become the basis of Metzger's mycological work. ${ }^{75}$ In their entirety, all of these

\footnotetext{
${ }^{70}$ Albert Michael Walter, 'Experimentelle Grundlagen und klinische Erfahrungen zur Antibiotika-Resistenz der Bakterien und der Resistenzverzögerung durch eine Kombinationstherapie', Habilitation: University of Freiburg, 1957.

${ }^{71}$ Ludwig Heilmeyer and Albert Michael Walter, Antibiotika-Fibel. Indikation und Anwendung der Chemotherapeutika und Antibiotika (Stuttgart: Thieme, 1954). In later editions, he co-authored the book with his co-researchers at Bayer: Albert Michael Walter et al., Antibiotika-Fibel. Antibiotika und Chemotherapie (Stuttgart: Thieme, 1969).

72 Domagk, Jahresbericht für 1958, BAL, 103/11.2.

${ }^{73}$ BAL 316/3.82 and 316/3.85 where the delivery of suspected resistant samples is documented. While in the early 1950 we see lots of spontaneous delivery with requests for determination of strains, the laboratory showed little interest in such activity after about 1955 and instead relied on collaboration with established partners.

${ }^{74}$ Minutes of a meeting 5.11.62 of the working group [Arbeitsgruppe] on antibiotics, sulphonamides and tuberculostatics, BAL, 372/29, 4: 'For preparations that are traded already it is impossible to employ excellent testers'.

75 BAL, 363/101; Baum, op. cit. (note 22): 253. Plans to employ a mycologist go back to 1961. Once hired, Metzger was sent on the customary training tour (Marget and Liebermeister, which were collaborating clinicians; Chabbert, a researcher at the Institut Pasteur). A short biography of Metzger is to be found in Axel A.H. Dalhoff,
} 
developments meant that pharmaceutical development in the early 1960s looked different from what it had been before. What had been an approach to market medicines for classical common infectious diseases like tuberculosis was about to be changed into a pipeline capable of identifying new targets of intervention, for example in relation to resistant Staphylococcus. At the same time Bayer, like other producers of medicines, changed its evaluation of clinicians and of their expertise in the research and development process. Slowly moving from advertising to marketing, clinicians came to be viewed as more than mere targets for information and instead came to be appreciated as providers of information on which drug researchers relied. ${ }^{76}$ As analysed for the example of research of cancer drugs, the later twentieth century saw the evolution of a situation in which basic science would not simply be informed by clinical medicine, but, instead, both spheres came to the entangled. ${ }^{77}$

The first visible result of this type of development and Bayer's first success with antibiotics was Binotal, Bayer's brand of the broad-spectrum antibiotic ampicillin. The semi-synthetic molecule as such was not Bayer's; it had been discovered by Beecham in the UK. Yet Bayer, capitalising on its traditional strength in chemical synthesis, found a more cost efficient way of mass producing the molecule and reached an agreement to divide markets with Beecham. ${ }^{78}$ The move towards semi-synthetic penicillins, so called 6-APA penicillins, was common amongst producers of antibiotics. It has been attributed to a situation where profits from first-generation antibiotics had been sliding substantially. One reason for this was that neither penicillin nor streptomycin were protected by patents and that the technology needed for their production had been actively disseminated by the WHO. ${ }^{79}$ As a consequence, the occurrence of resistance against penicillin and streptomycin was not entirely bad news for the pharmaceutical companies: resistance made less profitable antibiotics less useful and created a market for new generation antibiotics. Around 1960, penicillinase-resistant antibiotics seemed able to revive the antibiotic miracle. ${ }^{80}$ Presumably, like many other producers, Bayer seized the opportunity of launching medicines that would answer the problems created by the excessive application of first-generation antibiotics. While exploring the capabilities of ampicillin, Walter employed and developed Domagk's clinical development network and protocol for a new purpose.

During a press conference held at a medical congress in the summer of 1962 , Walter presented three new semi-synthetic penicillins. ${ }^{81}$ The presentation seems to have

'Discovery and Development of Anti-infectives at Bayer: A Personal View. Part III. Fluorquinolones', Sim News, 58, (2008), 89-105.

76 Jean-Paul Gaudillière and Ulrike Thoms, 'Introduction', in J.-P. Gaudillière and U Thoms (eds), Research for Sales: The Development of Scientific Marketing in the 20th Century Pharmaceutical Industry (London: Pickering and Chatto, forthcoming), 1-17. I thank the authors for sharing their unpublished work with me.

77 Ilana Löwy, Between Bench and Bedside: Science, Healing and Interleukin-2 in a Cancer Ward (Cambridge, MA; London: Harvard University Press, 1996); Alberto Cambrosio and Peter Keating, Biomedical Platforms. Realigning the Normal and the Pathological in Late-Twentieth-Century Medicine (Cambridge, MA: MIT Press, 2003), 50.

78 Baum, op. cit. (note 22), 131-3; H.G. Lazell, From Pills to Penicillin: The Beecham Story: A Personal Account (London: Heinemann, 1975), 177-9.

${ }^{79}$ Bud, op. cit. (note 3), 75-96; Greenwood, op. cit. (note 8), 122-6.

${ }^{80}$ Bud, op. cit. (note 3), 116-39.

${ }^{81}$ Kassler Post No. 230/Vol.80, 1.9.1962, 'Sieg über die Resistenz der Bakterien', in BAL, 363/101. The substances were Binotal (ampicillin), Stapenor (oxacillin) and Baycillin (propicillin). Cf. Dalhoff, op. cit. (note 26): 13. Cf. BAL, 363/101, 1.6.1962, Walter's memorandum on the coordinated introduction of the three medicines. 
highlighted an ongoing revival of the antibiotic miracle that was based on being able to tackle antibiotic resistance. Since the introduction of the original penicillin, nature had 'soto-speak gone to counter attack'. Resistant bacteria capable of inactivating antibiotics with the enzyme penicillinase had created an 'apparently hopeless situation' - out of which semi-synthetic penicillins offered a way out. Such medicines offered several advantages, two of which are of particular importance to our story:

3. One of these new penicillins, namely Baycillin [Bayer's brand of propicillin], has an enormous spectrum of activity that elsewhere is only found in so-called broad-spectrum antibiotics.

4. Another semisynthetic penicillin, Stapenor [Bayer's brand of oxacillin] furthermore has the advantage that penicillinase, which is the defensive ferments of the bacteria, can no longer destroy it.

Even germs which have proven to be resistant so far fall prey to the deadly action of these substances that have resulted from German-English collaboration.

In fact, the article points to a form of collaboration that allowed Bayer to increase its international standing. While none of the three antibiotics were Bayer's own molecules and the drugs' profitability thus lagged behind Bayers's pre-war sulphas, ${ }^{82}$ the company's strength in chemical synthesis played out in the mass production of semi-synthetic penicillins. While still lacking a substantial invention, this was, nonetheless, a step forward: Beecham and Bayer divided markets between them and, in addition to selling its own brand of the ampicillin, Bayer became a company active in refining crude semisynthetic penicillins for others. ${ }^{83}$ As a broad-spectrum antibiotic, ampicillin also indicates a shift in Bayer's development strategy away from medicines that were magic bullets directed against specific pathologies towards a medicine, whose quality lay in the opposite, namely, in delivering a shotgun reply to a host of infections. When discussing the market introduction of Propicillin in late 1961, Walter proposed to base the advertising of this medicine on its efficacy against a host of infections and specifically on its efficacy against resistant Staphylococcus:

Arguments for advertising

The following arguments for sales are to be accepted:

(1) Swift absorption and higher serum concentration, for that reason high titre and superior effect in streptococcal, pneumococcal and sensitive staphylococcal infections.

(2) Relative resistance to staphylococcal penicillinase. For that reason effective in moderately resistant (or partially resistant) resistant Staphylococci. Increased safety in all - sensitive or resistant staphylococcal infections. It should be the oral penicillin of choice in all Streptococcus, Pneumococcus and Staphylococcus infections. ${ }^{84}$

A related marketing strategy was pursued with the sulpha drug Durenat, a joint development with Schering that became available from 1960. In his market analysis for this year, Walter came to the conclusion that Durenat had clearly profited from the diminishing market share of first-generation antibiotics and had become Germany's best selling antiinfective chemotherapy, claiming a thirty per cent share of the market - even though that needed to be shared with the partner Schering. When it came to advertising, Walter

\footnotetext{
82 Bartmann, op. cit. (note 21), 309.

83 Dalhoff, op. cit. (note 26), 10.

${ }^{84}$ Walter's memorandum on the introduction of Bayer 5393 [propicillin]. 12.12.1961, BAL, 363/101. The memorandum is reporting a discussion in Walter's team on the marketing of the antibiotic and was addressed to employees in pharmaceutical marketing and development.
} 
said 'it was time to emphasize the scientific arguments in favour of Durenat in a fashion comparable to the way it was practised with Baycillin. ${ }^{85}$

We need not go into more detail, but we should be aware of the consequences. Bayer had traditionally been strong in the hospital market and it tried to reaffirm its position in this market segment by employing a new strategy. It was based on closely integrating laboratory and clinical research in the fashion described above for the tuberculostatics. This entailed both broad-spectrum preparations and medicines that were specifically designed to tackle resistant bacteria. When it came to the latter, Bayer still had to rely on buying licenses in the 1960s but was increasingly able to deliver some in-house development in the 1970s. ${ }^{86}$

If we step back for a moment and reflect on the type of pathologies that were targeted, we become aware that a fundamental change had occurred. It can be understood against the backdrop of a process in which, as already mentioned, pharmaceutical companies were slowly moving from advertising to marketing. This gave the researchers involved a heightened awareness of changes in their markets. Domagk, like presumably many other researchers of his generation, had aimed at a fairly static panorama of preferably common and serious infectious diseases like tuberculosis or pneumonia. Such orientation was based on the dominant philosophy of early twentieth-century public health expertise. By contrast, in the 1960s, Walter had realised that, in modern infection medicine, both pathologies and drugs were evolving quickly. ${ }^{87}$ Disease was no longer considered a static entity. Bayer's research pipeline was now guided by the search for transformed or new pathologies, such as those created by resistant staphylococcus. As a memorandum noted in the mid-1960s,

when it comes to developing new antibiotics the question of efficacy should not only be discussed in relation to [antibiotics'] good effect on sensitive germs. [Development] needs to focus on novel traits that would increase therapeutic safety which goes to say [antibiotics'] effectiveness in penicillin resistant staphylococci ${ }^{88}$

It is the new emphasis on antibiotic resistance - for which, ironically, second-generation antibiotics like methicillin seemed the ultimate answer - that is most striking here at first sight. However, the focus on broad-spectrum antibiotics, which Bayer shared with many other companies, also deserves closer inspection. We should be aware that the popularity of such medicines rose at a time when infection medicine was undergoing important changes. Challenges lay, not least, in the rising tide of hospital infections, often caused by socalled non-classical microbes. ${ }^{89}$ This reflected changes in the composition of hospital populations: with the mass arrival of the elderly, of those who had undergone cancer chemotherapy, and of patients who received organ transplants in increasing numbers, hospitals increasingly sheltered people with weakened immune systems. As a result, these patients were vulnerable to microbial infections, such as Pseudomonas or Klebsiella,

85 BAL, 363/101. Memorandum on the meeting of the 'working group [Arbeitsgruppe] chemotherapeutics: antibiotics, sulphonamides, tubculostatics', 5.11.1962. It reports on very good sales of Baycillin, while Stapenor is doing less well. Binotal only became marketed from 1.11.1961.

${ }^{86}$ Dalhoff, op. cit. (note 26) for an overview. The brand names with years of marketing and effective substances are: Stapenor (1962) Oxacillin; Resitopen (1972) Carbenicillin + Oxacillin; Microcillin (1973) Carbenicillin; Securopen (1977) Azlocillin; Baypen (1977) Mezlocillin. Azlocillin and Mezlocillin were own developments.

${ }^{87}$ Cf. letter by Walter to Bunge, 20.7.1960 (BAL, 372/27) where he states, on the example of the new antibiotic chloramphenicol, his opinion that any new antibiotic would be devalued by resistant bacteria over time.

${ }^{88}$ Undated memorandum, Bayer archives, BAL, 372/28. Judging from its positioning in the archive it should be from the mid-1960s.

${ }^{89}$ Flurin Condrau and Robert Kirk, 'Negotiating Hospital Infections: The Debate between Ecological Balance and Eradication Strategies in British Hospitals, 1947-69', Dynamis, 31, (2011), 385-405; Ayliffe and English, op. cit. (note 1). 
which would not cause clinical symptoms in healthy people. While, biologically speaking, such pathologies had little in common with those caused by resistant microbes, they were connected nonetheless: both were tied to the hospital environment outside of which they would not normally be found. Both were perceived as being new, and both would profit from appropriate antibiotic therapy. Seen from the perspective of the producers of medicines - that is to say as a market segment - these types of infection differed little. At Bayer, microbes of both sorts were even referred to by the same term. The term 'problematic germs' (Problemkeime), however, leaves entirely open the question of whether a germ is problematic as a result of its resistance or as a result of the impaired immunity of the host. A memorandum from 1981 identifies immune-compromised patients as a highly important market segment:

In human medicine, patients with impaired bodily immune response form a relevant part of the patient population. The causes for this are manifold and they reside on the one hand in severe basic condition (eg. tumors, accidents, cardiac conditions) on the other hand in therapy (cytostatics-immunosuppressants, radiation, antibiotics therapy). The approach of the team therefore resides in exploring new paths of anti-infective therapy for patients with impaired immunities..$^{90}$

As a consequence, the development of anti-infective medicines showed signs of change and stagnation at the same time. While being innovative in identifying new targets for intervention beyond classic, life-threatening infections, the notion that the answer to the challenges of hospital medicine lay in new drugs was upheld. ${ }^{91}$ What was crucial in understanding resistance and presumably also in new markets, as Walter put it in a memorandum in 1960, was clinical expertise. It required cooperation of microbiologists and clinicians - with the latter taking the lead. In an internal manual on resistance diagnostics, Walter explained whose knowledge counted most when it came to evaluating a test result: 'Any schematic evaluation of results is to be objected to. It results in discrepancies and quite often in fatal misjudgements. What is decisive for evaluating the determination of resistance is clinical experience and reflection. ${ }^{92}$ This certainly stood in contrast to Domagk's approach, who had viewed clinicians as people who were in need of advice rather than providing it. Clinicians for him had been 'helpless practitioners ${ }^{93}$ to be enlightened by laboratory researchers about drugs in general - and presumably also about resistance. Both Domagk and Walter were indebted to a tradition of ethical pharmaceutical marketing. The change from one to the other was about shifting focus when it came to identifying markets. Domagk focused on conditions that were part of the slowly developing landscape of common infectious disease; instead, Walter tried to monitor ongoing change. In 1973, the objectives of the B-lactam antibiotics team were defined in a manner that was suited to identifying change as it happened: 'What our investigations of $\beta$ lactam antibiotics aim for is to find preparations with better curative effects for conditions caused by so-called problematic germs. ${ }^{94}$

\footnotetext{
${ }^{90}$ State of the art report [Statusbericht] for 1980, working group immune defence, BAL, 323/104, of 28.1.1981.

${ }^{91}$ Bud, op. cit. (note 3), 116-39.

92 Memorandum on resistance determination, Walter, 30.9.1960, BAL, 372/27.

93 Quoted in Redeker, op. cit. (note 34), 100.

94 State of the art report [Statusbericht] for 1973, AK B-lactam-Antibiotika, BAL 323/99. Cf. Baum, op. cit. (note 22): 263-6 on Bayer's new antibiotics in the 1970s.
} 


\section{Lifestyle Infections}

In the 1960s, apart from intensifying collaboration with clinicians, Bayer also began to soften their exclusively chemical research tradition. In about 1963, as already mentioned, a medical mycology laboratory was installed and a microbiologist, Karl Metzger, was hired. ${ }^{95}$ Not much later, the old pathological institute was split in two with the infections department now being called the Institute for Medical Microbiology (while cancers and chronic conditions became allocated to a department of their own). From the 1970s onwards, Bayer, like other pharmaceutical companies, embarked on microbiological screening programmes - for example, for actinomycetes. However, when it came to envisioning new markets and drugs, focusing on the dynamic change of infections involved more than studying hospital related pathologies. It also facilitated a fresh view on infectious processes at large - providing the insight that earning serious money was by no means dependant on treating serious conditions. Instead, the medicalisation of lifestyle-related conditions would actually create new diseases - and markets. ${ }^{96}$ From the sulphas to penicillin, drug development for infectious diseases had focused on lifethreatening conditions. While being highly ethical, it was also a self-limiting marketing strategy. ${ }^{97}$ During the 1950 s, the search for therapeutic targets was widened to non-lifethreatening conditions. ${ }^{98}$ Bronchitis, to name a well-researched example, was transformed from an irritation that would only be treated in cases of complication into a condition that would profit from early intervention with antibiotics. ${ }^{99}$ What was needed were infectious processes that were widespread but which had been given little attention so far. Chronicity, which had come to be the prime focus of modern drug development, ${ }^{100}$ would be an added advantage. It was Bayer's new mycology laboratory that, in 1967, answered the call for a new kind of drug. Clotrimazole, better known under its brand name Canesten, was a treatment for fungal infections such as athlete's foot. Such conditions had been around for a long time. Of course, there were all kinds of treatments, but they were usually of poor efficacy. Given the widespread character of the condition, an effective molecule promised enormous income. ${ }^{101}$ Furthermore, the association between the infection's epidemiology and lifestyle factors, such as wearing sneakers and rubber boots or using indoor swimming pools, meant that repeated or even preventive application promised even better sales. In the words of Bayer's chronicler Hermann Baum, clotrimazole became a lottery winner, 'the first substance that offered real therapeutic progress' 102 that had come out of Bayer's development during the post-war period. An advertisement for it from the early 1970s (see figure 3) presents a medicine that supports a hygienic family life rather than fighting a dangerous infection.

Canesten was Bayer's own patent and could be marketed worldwide. Put on the market from 1973 and becoming an over-the-counter medicine later on, it became a real cash

95 Ibid.

96 Jeremy Greene, Prescribing by Numbers: Drugs and the Definition of Disease (Baltimore, MD: Johns Hopkins University Press, 2007).

97 Bartmann, op. cit. (note 21), 320.

98 Ibid., 339.

99 John T. MacFarlane and Michael Worboys, 'The Changing Management of Acute Bronchitis in Britain, 1940-

70: The Impact of Antibiotics', Medical History, 52, (2008), 47-72.

100 Greene, op. cit. (note 96).

101 Greenwood, op. cit. (note 8), 345-92. Aya Homei and Michael Worboys, Pathologies of Progress: Fungal Disease in Britain and the United States, 1850-2000 (Basingstoke: Palgrave, 2013).

102 Baum, op. cit. (note 22), 253. 


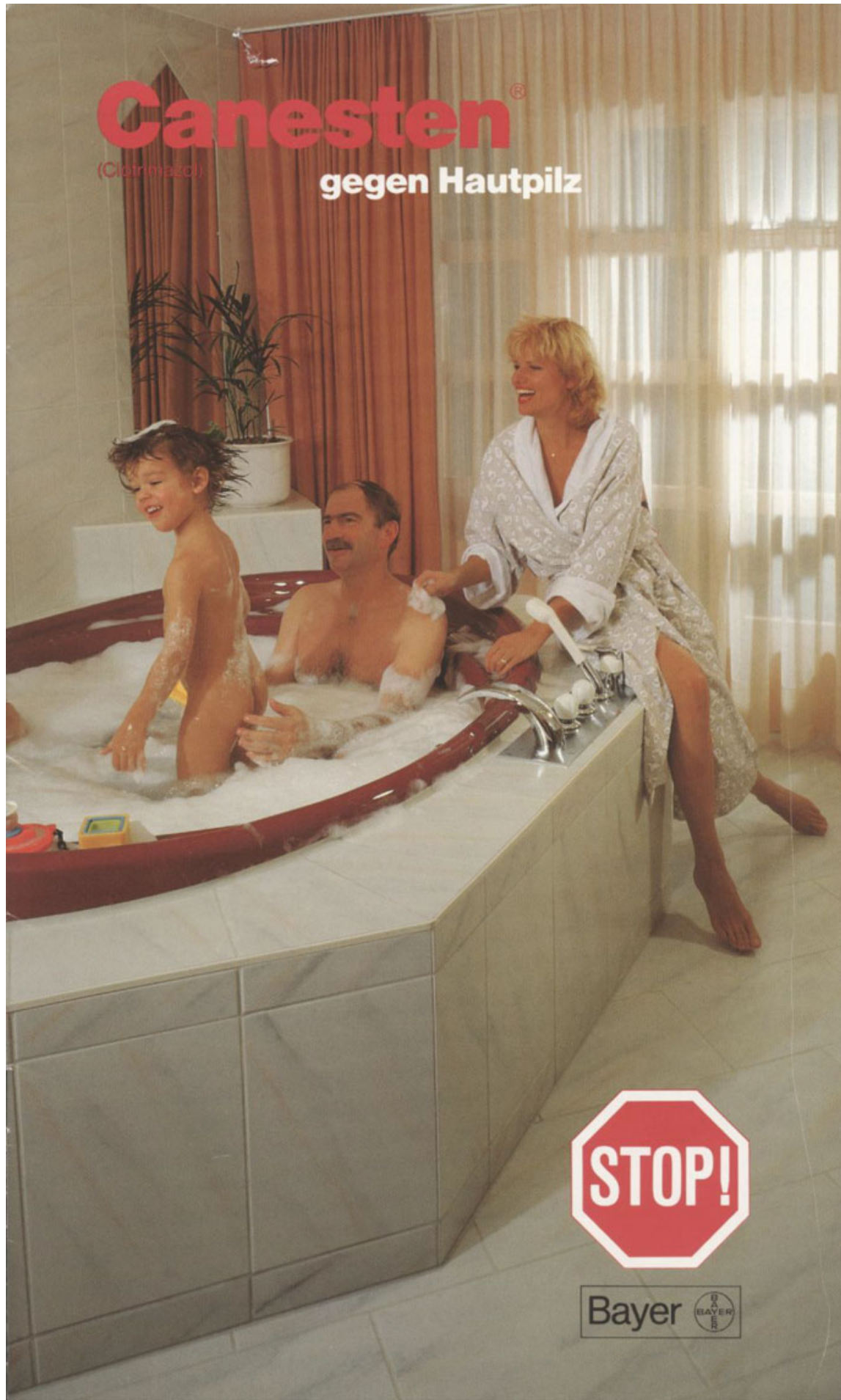

Figure 3: Canesten, supporting a healthy family life. Advertisement from the 1970s. BAL, 166/8. 
cow. It seems to have sidelined any other antifungal medicine. ${ }^{103}$ If we take a look at Bayer's turnover in pharmaceuticals for the year 1980, Canesten (179 million marks) was only surpassed by Adalat (223), an antihypertension drug, and Aspirin (214). Unlike the antibiotic Binotal (130), for which Bayer had acquired a licence from Beecham, which came rather close to Canesten in terms of turnover, Canesten also was Bayer's own molecule. ${ }^{104}$ Significantly, the two most successful preparations, Canesten and Adalat, targeted chronic conditions - despite the many differences that exist between angina pectoris and athlete's foot. ${ }^{105}$

Unfortunately, little information on the research and marketing strategy of Canesten has survived. However, a situation in 1975, when researchers were contemplating to repeat Canesten's success by focusing on herpes as a comparable condition, gives us a glimpse of how this might have been approached (see figure 4).

Translation:

'Herpes simplex:

Local manifestation, but systemic infection.

Type I as a model; Type II not tested for security reasons (possible oncogenicity)

Herpes-group:

1. Wide spreading.

2. Local application of virostatics: good effectiveness.

(cosmetic reasons; but for ex. Herpes corneae).

3. Viru-Merz: no effect but turnover !

4. Background: Herpes group $\rightarrow$ Transformation

$\downarrow$

secondary infection $\leftarrow$ Immune suppression

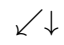

Chronic inflammations? Auto immune diseases?'106

Note that the exploration of market potential is really what the brainstorming was about. The first three of the four bullet points concern analysis of market potential, while the science of the condition is discussed as 'Background' and is in fourth position. Presumably, it would have figured prominently in Domagk's days. Profit could now be viewed independently from the seriousness of the condition in question and even from therapeutic efficacy. Commenting on a competitor's product (Viru-Merz), the authors stated that it has 'no effect, but turnover.'

103 Greenwood, op. cit. (note 8), 358.

104 Baum, op. cit. (note 22): 356. The numbers are in millions of Deutsche Mark.

105 Bartmann, op. cit. (note 21), 350 mentions that Adalat and Canesten in 1975 created three times as much turnover than ten other newly marketed preparations in those years.

106 BAL, 327/87. 


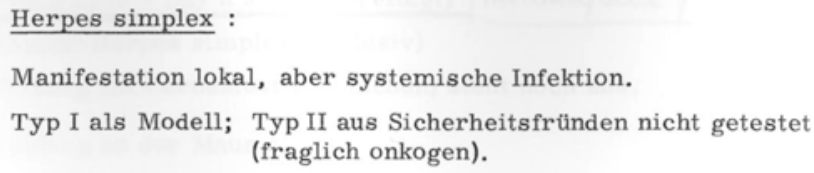

1. große Verbreitung.

2. lokale Anwendung von Virostatika : gute Wirksamkeit. (kosmetische Gründe; aber z.B. Herpes corneae).

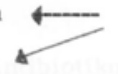

Figure 4: Brainstorming the market potential of a medicine for herpes, BAL, 327/87.

In the 1970s, the development of antibiotic medicines looked very different from what it had been 30 years before. First of all, Bayer now had three large screening programmes for antifungals, $\beta$-lactam antibiotics and actinomycetes - thereby finally employing on large scale a tool in drug development that had moved central to the work of the company's American competitors since the 1950s. ${ }^{107}$ What the company was trying to target in the late 1970s was nicely put by Karl Metzger during a meeting of the research committee in October 1977. Starting with a critical evaluation of what Bayer could offer, Metzger mentioned that Bayer's antibiotics were either broad in spectrum like Mezlocillin but sensitive to ß-lactamase or, like Oxacillin, narrow-spectrum but resistant to ß-lactamase. The ideal antibiotic would thus be a broad-spectrum preparation with two added capacities: 'What we are searching for is an antibiotic that can be applied without risk, to which as many as possible different bacteria are sensitive but should be resistant to $\beta$-lactamase so that all strains of the different species will be checked. ${ }^{108}$

Simultaneously, other work had been discontinued and this is most obvious in the case of tuberculosis, which also dropped off the radar of other drug companies and public health organisations in the period. ${ }^{109}$ In 1974, Bayer's high-ranking research committee decided that 'our envisioned extension in relation to bacteriostatic medicines should

\footnotetext{
107 Daemmrich, op. cit. (note 51), 55.

108 Research commission [Forschungskomission] pharma, minutes of the meeting 7.10.1977, 21.10.1977. BAL, 323/86. Cf. Research commission [Forschungskomission] pharma, minutes of the meeting 1.2.1974 (8.2.74), 'Target of Bayer's research is to find new B-lactam antibiotics, which combine the advantages of currently traded products (effectiveness in small quantities and concurrent low toxicity) but do not possess their disadvantages (limited antibacterial spectrum, sensitivity to pencillinase, triggering allergies, swift discharge, sometime a necessity to apply by drips)'.

109 Greenwood, op. cit. (note 8), 187/8. Cf. Linda Bryder, Flurin Condrau and Michael Worboys, 'Tuberculosis and its histories: then and now', in F Condrau and M Worboys (eds), Tuberculosis Then and Now: Perspectives on the History of an Infectious Disease, (Montreal: McGill-Queens University Press, 2010), 3-23.
} 
be partly balanced by cutting back on the tuberculosis sector. ${ }^{110}$ Two years later, that same committee sealed the coffin on the development of medicines for that condition stating 'that there is no therapeutic need for a new tuberculosis medicine in industrialised countries $[\cdots]$ (tb-treatment is merely a management problem)'. ${ }^{111}$ In fact, the crisis of Bayer's tuberculostatics was indicative of a structural problem that Bayer's traditional stronghold in medicines for common infections and tropical diseases entailed: having been inventions in their day, these medications now corresponded to an epidemiological landscape of the past - or of low income countries that could not afford them. In 1977, the research committee was informed about what the company's branch management for pharmaceuticals thought were 'Problemgebiete der Forschung' [problematic areas of research]:

(a) the area of malaria/trypanosomes is abandoned

(b) the areas bilharziosis, fasciolosis, filariasis are integrated together with the nematodes into the new area nematodes

(c) Research on tuberculosis is reduced to an in-vitro screening. ${ }^{112}$

\section{Infection and Innovation}

Bayer's strategy in relation to developing anti-infective medicines had been thoroughly modernised from about 1960 onwards. In marketing, chronic non-life-threatening conditions were targeted and new antibiotics for the hospital market were developed; in research, the exclusively chemical tradition was softened and microbiological screening programmes started. This happened against the backdrop of a successful international cooperation in the development of semi-synthetic antibiotics. It looked as though the company was finally able to escape from the strategic isolation into which its reliance on the sulphas had led it. ${ }^{113}$ However, costly as they were, screening programmes did not really deliver the blockbuster medicines that had been hoped for. Despite a few new antibiotics, clotrimazole was not a prelude to further successful developments. This meant that Bayer only partially escaped the fate of being a rather small producer, who was therefore heavily reliant on in-licensing medicines in order to appear as something it no longer was but still aspired to be: a global player. In 1968 for instance, Bayer would even take a licence for a medicine it believed had no market potential. The reason was that the company wanted to appear as a comprehensive producer to its clinical collaborators.

All in all what $\mathrm{I}$ have heard about Carbenicillin does not speak in favour of it being a smashing success and generating lots of turnover. To incorporate it into our portfolio has indeed been proposed by you for another reason, namely so that [our department for] Clinical Research would still be able to offer a substance to its clinical collaborators and will not be pushed out of contacts with clinics by other companies. ${ }^{114}$

The optimism around the screening programmes that had prevailed in the early 1970s gave way to scepticism towards the end of the decade. As far as we know, this was becoming widespread in the pharmaceutical industry in those days: it was dawning on companies that compared to other types of conditions, treating infections was - financially speaking - not rewarding.

${ }^{110}$ Research committee [Forschungskommittee] 1974, BAL 323/87.

111 Research committee [Forschungskommittee] 1976, BAL 323/87.

112 BAL 323/156, Department research [Ressort Forschung], minutes of a meeting held 10.1.77 (of 14.1.77).

113 Cf. Bartmann, op. cit. (note 21), 363.

114 BAL, 372/87, Letter Bartmann to Bunge, 29.8.1968. 
aus diesem Schema folgt, daß Chemotherapie und Stärkumg der wirtsspezifischen Abwehr keine alternativen Maßnahmen sein können, sondern kooperativ angewendet werden müssen. INFEKTIONSKRANKHEIT CHEMOTHERAPIE

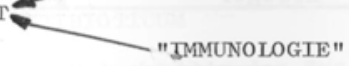

Therapieziel ist die Erhaltung des Wirtes, nicht primär die Abtötung des Erregers ( dies kann eine notwendige Methode_sein !!)

Andere Philosophie $! ! ! ! !$

FORSCHUNG:

INNOVATIONSPOTENTIAL THERAPIESTAND

\begin{tabular}{ll}
\hline CHEMOTHERAPTE & "TMMUNOLOGIE" \\
\hline NIEDRIG & HOCH \\
HOCH & -
\end{tabular}

Figure 5: Result of a brainstorming session in 1980. Produced for the workshop 'new approaches in infection control', BAL, 323/150.

Desperation was in the air and in this situation researchers were cautiously trying to think beyond the magic-bullet approach, which they had been following for almost eighty years. So far, their work had built on the assumption that curing infections was all about attacking the responsible pathogen. Held in 1980, a high profile workshop had the revealing title 'new approaches in infection control' and it illustrates the atmosphere of perplexity that was prevalent those days (see figure 5).

Translation:

$$
\begin{aligned}
& \text { 'from this schema it follows that chemotherapy and strengthening of host } \\
& \text { specific defence are no alternative measures. Instead they can be applied } \\
& \text { in cooperation. } \\
& \swarrow \text { Chemotherapy }
\end{aligned}
$$

INFECTIOUS DISEASE

$$
\nwarrow \text { 'Immunology' }
$$

The objective of therapy is the maintenance of the host, not primarily the control of the pathogen (this can be a necessary method !!)

Different Philosophy !!!!!

Research

CHEMO THERAPY "IMMUNOLOGY"

INNOVATIVE POTENTIAL LOW HIGH

LEVEL OF THERAPY HIGH LOW $^{115}$

115 BAL, 323/150. 
It is not so much the somewhat holistic rhetoric about strengthening host immunity as an approach that is telling here - the author, Bartmann, obviously feels uneasy about using the term immunology and places it in quotation marks - but the explicit statement that classical chemotherapy directed against the pathogen no longer held innovative potential. As the author maintained, the objective of therapy was to sustain the host, not, primarily, to kill the pathogen. In fact, researchers at Bayer were by no means alone in making this observation and we have good reason to assume that the frustration that Science reported in 1992 had prevailed in industry at least a decade earlier. ${ }^{116}$

Turning back to Bayer, an irony of our story lies in the fact that in the early 1980s another blockbuster antibiotic was just around the corner: in 1983 Bayer filed its patent for ciprofloxacin, yet another broad-spectrum antibiotic that was marketed from 1986. ${ }^{117}$ Cipro was aggressively advertised as a medicine to tackle resistance. The medicine was praised as 'Intelligent, fast, bactericidal' and, in an imagined autobiographical statement, a microbe would come to the sad conclusion: 'I was one of the resistant ones. Then I met with the unexpected.' 118 However, since the historian's insight is traditionally limited by archival laws that prohibit access to material more recent than thirty years, we cannot really comment further on this. Two observations, however, can be made: ciprofloxacin was not a molecule identified in one of the screening programmes; it was a chance discovery in a service laboratory. Also, it seems that this invention had no influence on the long-term strategy of the company, which, in fact, discontinued all research into infectious diseases and antibiotics in 2003. ${ }^{119}$

When it comes to Bayer's post-war history, we see two challenges, which the company shared with other producers of anti-infective medicine. Rather than focusing on molecular innovation, most companies' drug development, following the 1970s, was characterised by declining invention and revamping existing portfolios to keep profits flowing. In Bayer's case, this tendency was aggravated by being a comparatively small producer of antiinfectives and sitting on a relatively outdated product portfolio. It was this challenge which other German drug producers faced also and it limited their capacity to grow in a period of rapid internationalisation of drug companies. ${ }^{120}$ Having studied Bayer's pharmaceutical marketing during the 1960s, Heiko Braun has come to the conclusion that the company experienced an existential crisis in the years following World War Two. ${ }^{121}$ The look that we have taken at the development of anti-infective developments modifies this picture to some extent: we see a process that was initiated by the investment into semi-synthetic antibiotics around 1960 and by a modification in the research style. Innovation cycles in the pharmaceutical industry are usually long term and thus Bayer's comeback in the 1960 s, in part, resulted from its traditional strength in synthetic organic chemistry that

\footnotetext{
${ }^{116}$ Charles H. Stuart-Harris and David M. Harris (eds), The Control of Antibiotic-resistant Bacteria, (London; New York: Academic Press, 1982); John Mann, The Elusive Magic Bullet: The search for the Perfect Drug (Oxford: Oxford University Press, 1999); J. Parascandola (ed.) The History of Antibiotics: Symposium, (Madison, WI: American Institute of the History of Pharmacy, 1980). Greenwood, op. cit. (note 8), 262-3. Rang, op. cit. (note 9), 16-17; Spellberg et al., op. cit. (note 9).

117 Work had started in 1981. On ciprofloxacin: Dalhoff, op. cit. (note 75), 92-6.

118 Quotes from an advertising poster campaign for Ciprofloxacin, BAL, 166/8.

119 Dalhoff, op. cit. (note 75), 100.

${ }^{120}$ Viviane Quirke and Jean-Paul Gaudillière, 'The Era of Biomedicine: Science, Medicine, and Public Health in Britain and France after the Second World War', Medical History, 52, (2008), 441-52, here 451.

${ }^{121}$ Braun, op. cit. (note 26), 140.
} 
paid off when semi-synthetic antibiotics became fashionable. ${ }^{122}$ However, the revival can not be reduced to that and the reliance on traditional strengths was accompanied by a broadening of technological resources through microbiological screening and, most of all, a research and development focus that embraced the evolution of infectious disease. It entailed focusing on the hospital market and exploring the novel market segment of lifestyle infectious disease. As a result, in the 1970s, we see a company about to escape from the hard haul that had resulted from its previous framing of markets and lack of molecular invention that had resulted from not participating in the development of firstgeneration antibiotics. All this seemed to culminate in the discovery of another blockbuster antibiotic around 1980. If, however, cipro made a difference, it did so only for Bayer. Internationally, antibiotics development continued to slide all the way to the end of the century.

Let us conclude with a few words on stories beyond the scope of a single company. To the historian, it seems that the therapeutic revolution, which, as far as antibiotics are concerned, began in the 1930s, was quite limited in time and was more or less over a generation later. Investigating the causes of why it was short lived, this paper opened by questioning the simple notion of an empty drug development pipeline in which ingenious resistant bacteria outsmarted an aspiring pharmaceutical industry. In fact, the pharmaceutical industry - if the example of Bayer allows for some generalisation - initially embraced the phenomenon of antibiotic resistance since it seemed to offer exciting new markets. When strategies to profitably exploit this segment came into crisis, scepticism as to whether anti-infective medicines could be profitable in the first place was ensuing. The pipeline, it seems, did not run dry. It looks more like it was abandoned.

Note on archival sources:

All quotes from the archives of Bayer AG (BAL) are translations from German by the author.

${ }^{122}$ Louis Galambos and Jane Eliot Sewell, Networks of Innovation: Vaccine Development at Merck, Sharp and Dohme, and Mulford, 1895-1995 (Cambridge: Cambridge University Press, 1996), 241-3 have emphasised a similar pattern in their study of Merck, Sharp \& Dome's vaccine business. 